\title{
PENGEMBANGAN KOMPETENSI DIGITAL ACADEMICS WRITING BERBASIS COSTUNTUK REMAJA DI PURI CINERE HIJAU DEPOK
}

\author{
Anita Diana ${ }^{1}$, Reva Ragam Santika ${ }^{1}$ \\ ${ }^{1}$ Universitas Budi Luhur, Jakarta, Indonesia \\ anita.diana@budiluhur.ac.id
}

\begin{abstract}
Abstrak: Tujuan Pengabdian Kepada Masyarakat (PKM) ini adalah untuk meningkatkan pengetahuan dan keterampilan kepada para remaja tentang membuat digital academics writing yang berbasis COST (comprehensive, objective, systematic, trusted) sehingga dapat Meningkatkan wawasan pengetahuan tentang menulis makalah atau karya tulis yang baik dan benar. Disamping itu juga meningkatkan hubungan dan kerjasama antara Universitas Budi Luhur dengan Warga Puri Cinere Hijau Depok sebagai mitra. Metode yang digunakan adalah survey, wawancara, penyampaian materi dan praktikum serta memberikan kuesioner sebagai feedback dari mitra dan evaluasi dari kegiatan PKM. Kesimpulan dari kegiatan ini menunjukkan bahwa pelatihan penggunaan aplikasi Microsoft Word dalam pembuatan digital academics writing yang berbasis COST berjalan dengan baik dan terbukti berdasarkan Analisis angket menunjukkan bahwa respon remaja terhadap Evaluasi pelatihan untuk meningkatkan keterampilan dalam Digital Academics Writing berbasis COST dengan rata-rata persentase sebesar $71 \%$. Serta berdasarkan hasil evaluasi proses pelatihan menunjukkan $90 \%$ peserta setuju isi materi pelatihan jelas dan mudah dipahami, $80 \%$ Tutor memberi kesempatan untuk bertanya, $90 \%$ peserta sangat setuju bahwa tutor mampu menjawab pertanyaan peserta dengan jelas, $70 \%$ Peserta setuju bahwa tutor membantu dalam memahami materi yang disampaikan contoh latihan jelas dan mudah dipahami. Pelatihan ini meningkatkan kompetensi remaja dalam bidang menulis makalah atau bentuk digital academic writing lainnya serta memiliki dampak sangat positif bagi remaja khususnya pelajar dan mahasiswa dalam menyelesaikan tugas harian sekolah atau kampus dan juga sebagai modal dalam penyusunan makalah dan skripsi nantinya.
\end{abstract}

Kata Kunci: digital academics writing, COST

\begin{abstract}
This community service aims to increase teenagers' knowledge and skills on how to make Digital Academics Writing based by COST (comprehensive, objective, systematic, trusted) to increase their writing quality. It also improves relations and cooperation between Budi Luhur University and the partner (Puri Cinere Hijau Depok residents). The methods used were surveys, interviews, expository, and practicum. Questionnaires were also given to the participants as an evaluation of the program. The training on using Microsoft Word application to create Digital academic Writing based on COST was running well. The questionnaire results showed that the program improved participants' Digital Academics Writing skills based on COST with $71 \%$ average. The evaluation of the training reveals that $90 \%$ of the participants agreed that the training content is clear and understandable, $80 \%$ agreed that the tutor facilitated a discussion, $90 \%$ strongly agreed that the tutor could answer the participants' questions clearly, and $70 \%$ agreed that tutor had helped the participants to understand the delivered lesson, and appropriately given the exercises. The program has improved the participants' competence in writing papers or another digital academic writing form. Also, it gives a strong positive impact on school students and university students to complete their daily school or college tasks and as a preparation for writing the thesis.
\end{abstract}

Keywords: digital academics writing, COST

\section{Pendahuluan}

Penulisan karya ilmiah atau academic writing adalah suatu karangan yang disusun secara sistematis dan sehingga pembuatannya memenuhi kaidah ilmiah, yang dinamakan sistematis 
ialah disusun menurut aturan tertentu sehingga kaitan antar setiap bahasan satu dengan yang lain berkait jelas dan padu (Press, 2018). Penulisan karya ilmiah memerlukan kompetensi menulis karena ini sangat dibutuhkan dalam proses pembelajaran, selain kompetensi membaca, kompetensi berbicara, dan kompetensi mendengarkan. Kompetensi menulis digunakan untuk mengungkapkan pikiran, gagasan, dan pendapat siswa dalam bentuk tulisan. Aktivitas menulis merupakan suatu bentuk manifestasi kemampuan dan keterampilan berbahasa yang paling akhir dikuasai pelajar bahasa setelah kemampuan mendengarkan, berbicara dan membaca (Aminatun, 2017)

Menulis merupakan suatu kegiatan yang sangat berkaitan erat dengan bidang akademik, bagi seorang pelajar terutama dalam hal pembuatan karya ilmiah. Dalam penyusunan karya ilmiah yang ditugaskan oleh guru biasanya dalam bentuk artikel ilmiah dan makalah. Karena dalam penulisan karya ilmiah ini siswa diharapkan dapat mengkomunikasikan informasi, pengetahuan baru, gagasan, kajian, dan hasil penelitian (Persadha, 2016). Oleh karena itu perlu adanya pembekalan siswa tentang bagaimana cara menulis yang baik, agar setiap hasil tulisan dapat diapresiasikan sehingga mampu meningkatkan kemampuan siswa dalam menghasilkan karya tulis yang lebih baik.

Akan tetapi pada kenyataan nya tidak semua siswa memiliki kemampuan yang baik dalam hal academic writing, terlebih lagi di era Digital saat ini pembuatan karya ilmiah dan makalah sudah menggunakan perangkat teknologi salah satunya adalah pengolah kata seperti Microsoft Word, sehingga penulisan karya ilmiah ssat ini lebih dikenal dengan nama digital academics writing, Masih banyak siswa yang belum memiliki kemampuan yang baik dalam mengoperasikan Microsoft Word, terutama dalam pembuatan digital academic writing berbasis COST (comperehensive, objective, systematic, trusted). Dalam pembuatan digital academic writing baik itu karya ilmiah maupun makalah harus lah memahami sistematika dan teknik penulisan karya ilmiah yang baik dan benar terutama dalam pembuatan makalah berbasis COST (comperehensive, objective, systematic, trusted). Menurut Munawwaroh (2018) dalam pembuatan makalah haruslah memperhatikan tahapan-tahapan yang meliputi tahap persiapan, tahap penulisan, dan tahap pemeriksaan. Tahap persiapan meliputi beberapa kegiatan antara lain: (1) mengumpulkan referensi-referensi yang terkait dengan judul makalah yang akan dibuat, (2) membaca buku-buku yang dijadikan refrensi dalam penulisan makalah agar dapat membentuk kerangka berfikir dan memperluas pengetahuan yang berhubungan dengan judul makalah, (3) mengembangkan kerangka makalah. Selanjutnya tahap penulisan, yaitu kegiatan pengembangan kerangka makalah menjadi sebuah makalah. Tahap ini dapat dilakukan melalui beberapa aktivitas antara lain: (1) mengkaji berbagai sumber yang didapat terkait dengan judul makalah, (2) memperhatikan teknik penulisan dalam penyajian makalah, (3) menguraikan intisari pemahaman penulis terhadap informasi yang dituangkan dalam makalah berdasarkan sumber yang didapat. Berikutnya adalah tahap pemeriksaan dimana pada tahap ini penulis melakukan pemeriksaan isi makalah terkait dengan ejaan, penggunaan kata, kalimat dan bahakan tanda baca sesuai dengan kaedah Bahasa Indonesia yang baik dan benar (Munawwaroh, 2018) 
Berdasarkan hasil wawancara awal dengan Peserta dan juga Ketua RT pada perumahan Puri Cinere Hijau di Kelurahan Rangkapan Jaya Baru Kota Depok Jawa Barat bahwa para remaja tidak semua mempunyai kemampuan yang baik dan merata dalam mengoperasikan Microsoft Word. Sehingga mereka membuat makalah laporan atau karya tulis dengan kemampuan seadanya, tanpa dibekali dengan ilmu yang benar terutama dalam pemanfaatan tools layouting Makalah. Untuk itu, kegiatan pelatihan ini dirasakan penting bagi para remaja SMP dan SMA pada perumahan Puri Cinere Hijau agar dapat membuat makalah, laporan atau karya tulis yang baik. Hal ini dapat bermanfaat pula untuk pembuatan dokumentasi kegiatan dalam dan di luar sekolah. Disamping itu juga penguasaan kemampuan Digital Academic Writing tidak hanya untuk pembuatan tugas sekolah akan tetapi juga membantu para remaja yang tergabung dalam karang taruna dalam membuat proposal dan laporan kegiatan karang taruna ataupun kegiatan masyarakat.

Hasil pengabdian masyarakat sebelumnya menunjukkan pentingnya penguasaan teknologi terutama dalam hal meningkatkan kompetensi siswa. Sebagaimana yang dipaparkan oleh Ikhwani (2015) yang menyimulkan bahwa dari kegiatan PKM yang dilakukan siswa dapat menjalankan Microsoft word dengan baik, memanfaatkan tools yang ada di Microsoft Word dengan baik serta dapat menggunakan Microsoft word sesuai dengan keperluan masing masing. Pelatihan dalam penggunaan Microsoft Word bagi pelajar juga dilakukan oleh (Sari, Fitriyani, \& Prabandari, 2020) dalam artikel terpublikasi yaitu "Optimalisasi Penggunaan MS. Word dan MS. Excel Pada Siswa SMP PGRI Astra Insani Bekasi" dalam pelatihan ini para peserta pelatihan dapat memaksimalkan penggunaan memanfaatkan fasilitas-fasilitas yang ada di dalam Microsoft Word dengan baik sehingga mampu untuk meningkatkan kompetensi dibidang ilmu komputer yang mampu menunjang pembelajaran di sekolah. Pemanfaatan Microsoft Word juga memiliki peranan sangat penting dalam penulisan makalah dan karya tulis seperti yang uraikan dalam laporan pengabdian masyarakat (Hernawati, 2013) dengan judul " Optimalisasi Pemanfaatan fitur Microsoft Word dalam Penyusunan Artikel Ilmiah Bagi Guru", dalam pelatihan ini dijelaskan bahwa masih minimnya pemanfaatan fitur - fitur Microsoft Word secara optimal dalam penyusunan karya ilmiah, seperti daftar isi,daftar pustaka, daftar tabel/daftar gambar, indeks, glosarry, citation dan sebagainya secara otomatis. Hasil dari pelatihan ini adalah meningkatnya kompetensi guru dalam penggunaan fitur - fitur terkait penulisan ilmiah. Kesimpulan dari publikasi kegiatan PKM yang telah dilakukan sebelumnya yaitu, dengan dilakukan pelatihan pemanfaatan secara optimal fitur - fitur yanga ada di dalam Microsoft Word terutama terkait digital academic writing memberikan manfaat bagi masyarakat terutama masyarakat yang berprofesi sebagai guru dan juga siswa dalam kemampuan dalam pembuatan karya ilmiah baik untuk kepentingan publikasi maupun pembuatan makalah untuk tugas sekolah yang berkualitas. Oleh karena itu berdasarkan atas kegiatan pengabdian masyarakat yang telah dijabarkan didalam artikel sebelumnya hanya memberikan pelatihan terkait penggunaan fiturfitur yang terdapat dalam Microsoft Word dalam pembuatan digital academic writing tetapi tidak menjabarkan bagaimana membuat karya tulis yang memiliki kajian pustaka yang relevan dengan tema makalah (comprehensive), menerapkan fakta dan informasi sesuai dengan 
kerangka ilmiah (objective), memiliki struktur penulisan yang sesuai standard (systematic) dan bagaimana memasukan sumber referensi yang kredibel kedalam karya ilmiah (trusted).

Kegiatan pengabdian masyarakat ini bermitra dengan warga di Perumahan Puri Cinere Hijau yang memiliki jumlah Kepala Keluarga sebanyak 109 Kepala Keluarga dan 372 jumlah jiwa, dengan Pasangan Usia Subur (PUS) sebanyak 78, anak dan remaja usia 10-25 tahun sebanyak 146, jumlah Balita sebanyak 19 dan jumlah Lansia sebanyak 13. Di perumahan ini terdapat anak dan remaja usia 10-25 tahun sebanyak 146 orang, dengan 30 jumlah remaja SMP, dan 26 jumlah remaja dalam pengabdian masyarakat ini sasaran target peserta adalah anak usia remaja yang berstatus pelajar SMP dan SMA.

Berdasarkan data survei awal TIM PKM di Puri Cinere Hijau sekitar 70\% warga Puri Cinere Hijau mengidap Buta IT. Yang menjadi sangat miris Buta IT bukan saja disandang oleh orang dewasa namun sebagian besar Remaja juga mengidap buta IT. Padahal Selama Masa Pandemik, para remaja yang saat ini berstatus sebagai pelajar dan mahasiswa lebih banyak belajar di rumah dan terkadang sering mendapatkan tugas dalam bentuk makalah atau karya tulis. Tentunya ini menyulitkan para remaja dalam membuat tugas tersebut dikarenakan ketidaktahuan mereka tentang fitur - fitur Microsoft Office serta Teknik dalam membuat digital academic writing yang berbasis COST seperti bagaimana cara mancari dan menerapkan kajian pustaka yang tepat dalam makalah, memasukan fakta dan informasi yang sesuai dengan kerangka ilmiah, menulis sesuai dengan struktur penulisan yang standard dan bagaimana memasukan referensi yang kredibel kedalam makalah masih tidak diketahui oleh remaja, karena ketidaktahuan inilah mengakibatkan tidak adanya minat dan semangat serta motivasi remaja dalam berkarya khususnya menulis sebuah karya tulis.

Adapun solusi yang diberikan terhadap permasalah mitra PKM adalah: (a) dengan memberikan dan mengadakan pelatihan yang disesuaikan dengan kebutuhan mitra dalam bidang IT. (b) Memberikan pendalaman materi tentang cara menulis sebuah karya tulis dengan baik dan benar agar masyarakat, khususnya remaja pada perumahan Puri Cinere Hijau tentang penulisan digital academic writing Berbasis COST. (c) memberikan informasi tentang adanya Lomba Karya IImiah Daerah/Nasional atau kompetisi-kompetisi essay nasional yang hadiahnya cukup menarik dan menggiurkan, disertai pemberian contoh-contoh makalah yang baik, sehingga menumbuhkan minat, semangat serta motivasi remaja dalam berkarya.

Tujuan dari kegiatan PKM ini bagi Mitra Remaja di Perumahan Puri Cinere Hijau adalah (a)Membantu memberikan pengetahuan tentang Microsoft Word, terutama untuk penulisan makalah atau karya tulis. (b) Meningkatkan wawasan pengetahuan tentang menulis makalah atau karya tulis yang baik dan benar. Termasuk meningkatkan wawasan pengetahuan tentang mengoperasikan Microsoft Word yang baik dan benar terutama yang berkaitan dengan digital academic writing (c). Untuk menumbuhkan minat dan potensi, serta meningkatkan semangat dan motivasi setiap remaja dalam berkarya khususnya di bidang menulis sebuah karya tulis yang berbasis COST .

Karena keterampilan menulis karya ilmiah berbasis COST dimana karya tulis yang dihasilkan adalah hasil karya yang memiliki kajian yng relevan dengan tema makalah (comprehensive), mampu menerapkan fakta dan informasi sesuai dengan kerangka ilmiah 
(objective), Memiliki struktur penulisan yang sesuai standard (systematic) dan memasukan sumber referensi yang kredibel kedalam karya ilmiah (trusted). Kesemua itu merupakan salah satu kemampuan penting bagi siswa maupun mahasiswa dalam rangka memenuhi tuntutantuntutan akademik selama masa sekolah maupun perkuliahan, seperti menyusun makalah, menyusun laporan observasi, menulis buku, sampai dengan menyusun skripsi atau tugas akhir. Bahkan keterampilan menulis karya ilmiah juga penting bagi siswa dalam menuju ke arah masyarakat akademik di perguruan tinggi dalam rangka menyemarakkan dan menggairahkan kebudayaan nasional dalam menyongsong perkembangan arus informasi dewasa ini.

\section{Metode}

Tahapan yang dilalui mulai dari persiapan kegiatan PKM hingga pembuatan laporan kegiatan PKM dilakukan selama 4 bulan yaitu pada bulan Maret samapai dengan Juni 2020 yang dijabarkan sebagaimana pada gambar 1.

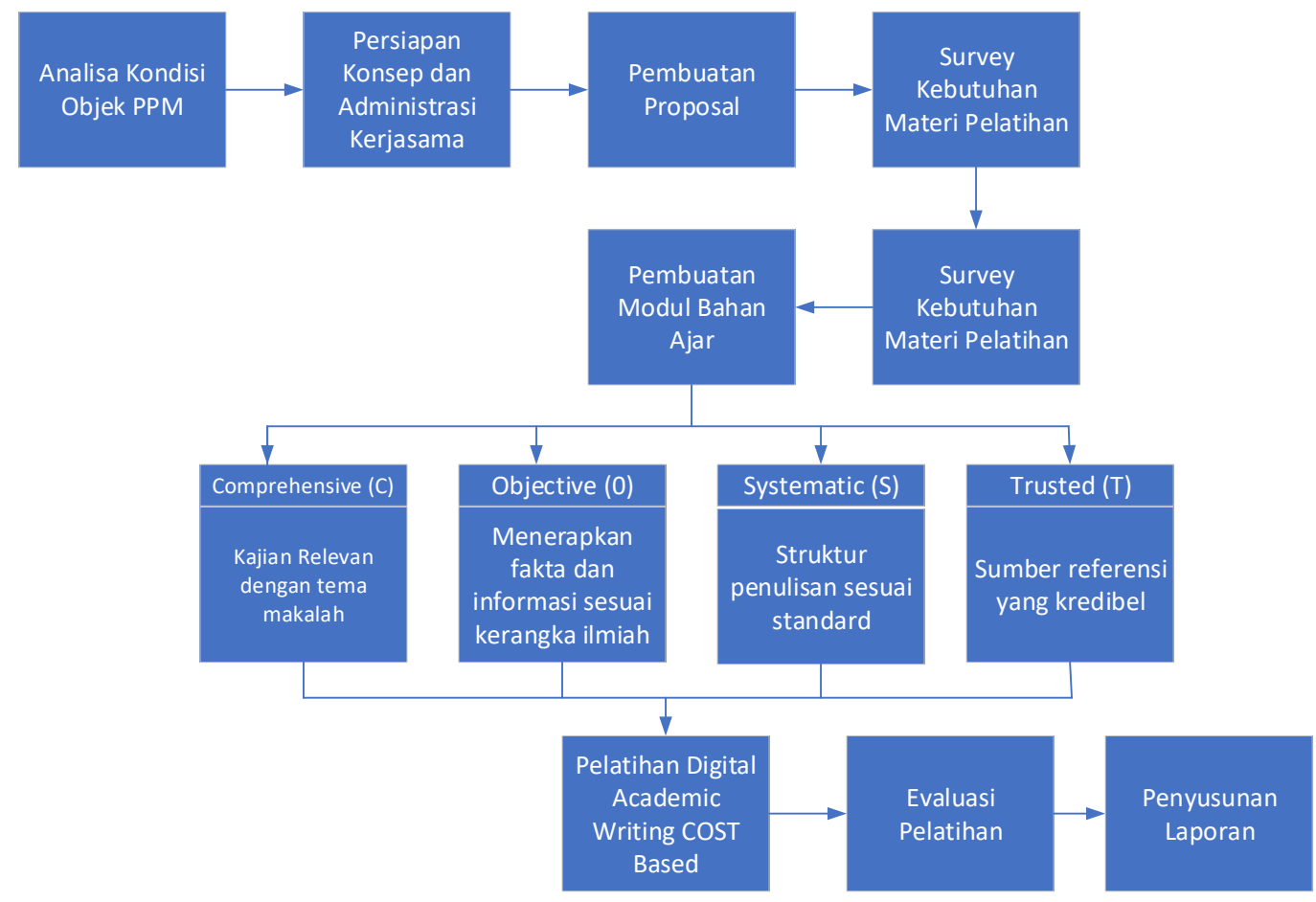

Bagan1. Tahapan kegiatan pengabdian Masyarakat

Uraian kegiatan program pengabdian kepada masyarakat adalah sebagai berikut :

a. Analisa kondisi obyek PPM: mengadakan survei atau wawancara kepada mitra pengabdian masyarakat yaitu ketua ikatan remaja dan masyarakat yang merupakan target pelaksanaan program pengabdian masyarakat, untuk mengumpulkan informasi terkait kebutuhan materi pelatihan yang dibutuhkan oleh peserta pelatihan.

b. Persiapan konsep dan Administrasi kerjasama: koordinasi dan persiapan kegiatan pengabdian kepada masyarakat dan pengajuan permohonan kerjasama dari mitra kepada Universitas Budi Luhur. 
c. Pembuatan Proposal: Membuat proposal kegiatan pengabdian kepada masyarakat merupakan salah satu syarat pengajuan untuk permohonan pelaksanaan kegiatan pengabdian masyarakat sekaligus pengajuan dana hibah operasional untuk pengabdian masyarakat internal di Universitas Budi Luhur.

d. Survei kebutuhan materi pelatihan: mengadakan diskusi dengan mitra terkait materi pelatihan dan mengajukan peminjaman laboratorium komputer di Universitas Budi Luhur, setelah mendapatkan kesepakatan tentang hari pelaksanaan pengabdian masyarakat.

e. Pembuatan modul dan bahan ajar: Membuat modul dan bahan ajar sesuai dengan kesepakatan akan kebutuhan materi yang dibutuhkan mitra terutama terkait tentang digital academics writing. Dalam penyusunan ini tim tutor membuat modul digital academic writing yang berbasis COST yaitu:

Comprehensive : hasil karya yang memiliki kajian yng relevan dengan tema makalah, dimana kajian tersebut mampu menjelaskan keterangan secara lengkap dan luas serta memberikan wawasan yang lebih.

Objective : : mampu menerapkan fakta dan informasi sesuai dengan kerangka ilmiah Berdasarkan apa yang ada di lapangan

Systematic : Memiliki struktur penulisan yang sesuai standard dan memiliki urutan yang runut disertai analisis yang logis dan objektif

Trusted : : memasukan sumber referensi yang kredibel kedalam karya ilmiah

f. Pelatihan penguasaan aplikasi yang mendukung digital academic writing yaitu Microsoft Office Word. Tahapan ini akan dilakukan dengan 2 cara yaitu :

1) Sosialisasi dengan memberikan ceramah, tanya jawab dan diskusi. Metode ceramah menurut (Wahab, 2012) dimana guru menyampaikan pelajaran dengan membaca dari buku dan mendiktekan pelajaran dengan penggunaan buku. Diskusi menurut (Nasih, 2013) adalah metode diskusi merupakan metode pembelajaran yang tepat untuk meningkatkan kualitas interaksi antara peserta didik. Bentuk sosialisasi dilakukan dengan cara sebagai berikut :

a) Memberikan informasi dalam bentuk ceramah kepada peserta tentang pengenalan tentang digital academic writing dan memberikan contoh tentang bagaimana membuat digital academic writing yang sesuai dengan kajian sumber pustaka yang relevan serta melakukan pemaparan tentang bagaimana struktur penulisan karya Ilmiah yang baik.

b) Melakukan pemaparan dan diskusi ringan mengenai bagaimana menghindari plagiat dalam penulisan makalah serta memberikan persuasi untuk menumbuhkan minat peserta dalam menuangkan ide kedalam penulisan sebuah karya ilmiah yang baik.

2) Pelatihan Komputer dilakukan dengan metode workshop. Merupakan sebuah metode yang berbentuk program pelatihan yang padat dan singkat. Materi pelatihan diberikan dalam bentuk softcopydan juga hardcopykepada peserta sehingga para peserta dapat dengan mudah mengikuti materi pelatihan dan dapat dijadikan sebagai bahan praktikum oleh peserta. 
Secara rinci, berkut ini adalah metode dalam penyampaian materi tersebut dapat tergambar jelas dalam tabel 1.

Tabel 1. Rangkaian kegiatan Pelatihan

\begin{tabular}{lllc}
\hline No & \multicolumn{1}{c}{ Materi } & Metode & Durasi \\
\hline 1. & Esensi digital academic writing & Ceramah & 45 Menit \\
\hline 2. & $\begin{array}{l}\text { Memaparkan Esensi makalah } \\
\text { sesuai dengan kajian sumber } \\
\text { pustaka yang relevan dengan tema } \\
\text { makalah (Komprehensif) }\end{array}$ & Workshop & $2 \times 45$ menit \\
\hline 3 & $\begin{array}{l}\text { Memaparkan fakta dan informasi } \\
\text { dalam kerangka ilmiah serta } \\
\text { Mengutip, memparafrase dan } \\
\text { meringkas tulisan yang disitasi } \\
\text { (Objektif) }\end{array}$ & Workshop & $2 \times 45$ menit \\
\hline 4 & $\begin{array}{l}\text { Membuat makalah sesuai dengan } \\
\text { struktur penulisan karya Ilmiah } \\
\text { (Sistematis) dengan menggunakan } \\
\text { tools yan ada di Microsoft Word }\end{array}$ & Workshop & \\
\hline 5 & $\begin{array}{l}\text { Mancari sumber referensi yang } \\
\text { relevan dengan topik dan menulis } \\
\text { daftar pustaka sesuai dengan } \\
\text { konvensi ( Trusted) }\end{array}$ & Workshop & \\
\hline 6 & Evaluasi Hasil penulisan & & \\
\hline
\end{tabular}

g. Evaluasi Kegiatan: Menyebarkan kuesioner kepada peserta pelatihan komputer "pelatihan digital academics writing dalam meningkatkan keterampilan siswa di bidang digital academics writing pada remaja Puri Cinere Hijau" untuk mendapatkan feedback dari pelatihan yang telah dilaksanakan sebagai bahan evaluasi untuk perbaikan kegiatan pelatihan di masa mendatang.

\section{Hasil dan Pembahasan}

Pada bagian ini akan sampaikan hasil kegiatan pengabdian kepada masyarakat (PKM), dan dokumentasi kegiatan PKM serta hasil evaluasi kegiatan PKM yang berbentukgrafik

\section{Hasil Kegiatan}

Pada kegiatan PKM ini tim memberikan pelatihan kepada Remaja dari Puri Cinere Hijau, Depok, dari total rencana 20 orang peserta yang mendaftar, saat pelatihan hanya 10 orang peserta datang. Seluruh peserta mengikuti pelatihan digital academics writing dengan menggunakan aplikasi Microsoft Office yaitu Microsoft Word, pelatihan dimulai dengan membuat struktur halaman, cover, kata pengantar, table of contents dan penomoran halaman yang berbeda dan sitasi. Dalam situasi pandemic Covid-19, pelatihan dilakukan dengan mengikuti prosedur kesehatan pencegahan Covid-19, dan pelatihan dilakukan dengan menggunakan media video conference dengan menggunakan Google Meet. Walaupun dalam kondisi tersebut, peserta mampu mengikuti semua rangkaian materi yang disampaikan serta berhasil mengerjakan tugas yang diberikan. Peserta pelatihan dapat mengikuti semua rangkaian kegiatan praktikum dengan baik sampai dengan selesai. 


\section{Dokumentasi Kegiatan Pengabdian}

Pada gambar1, instruktur utama sedang memberikan penjelasan melalui media video conference menyampaikan langkah-langkah membuat digital academics writing dengan Microsoft Word. Pada sesi ini peserta diajarkan cara membuat struktur halaman, cover, kata pengantar, table of contents dan penomoran halaman yang berbeda.
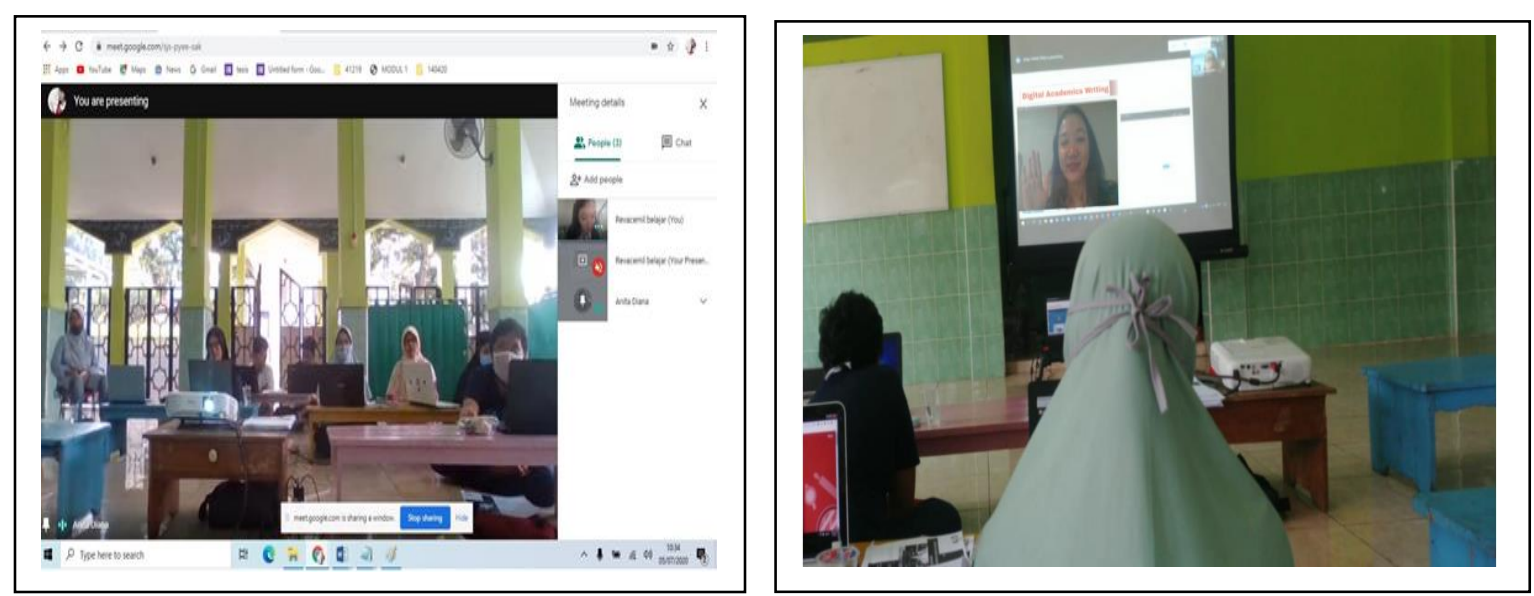

Gambar 1. Tutor 1 memberikan materi pelatihan melalui Video conference (dari sisi tutor dan peserta)

Pada gambar 2, para peserta dan tutor kedua sebagai instruktur lapangan memperhatikan langkah-langkah yang disampaikan oleh tutor pertama tentang langkah langkah di dalam pembuatan digital academics writing.

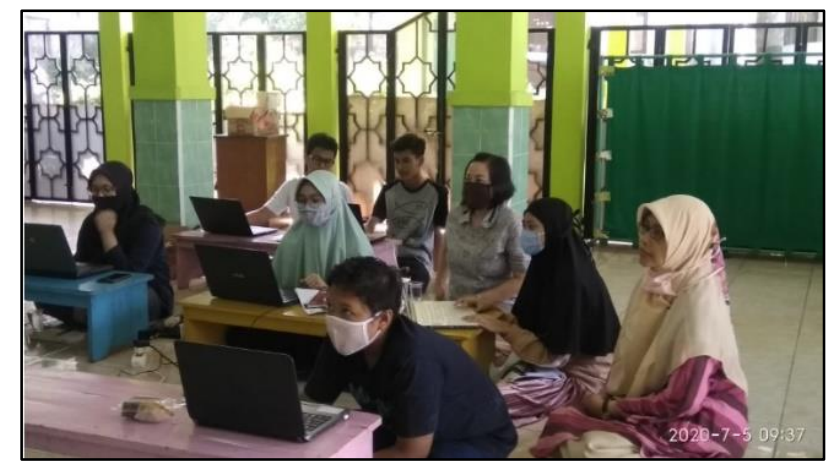

Gambar 2. Peserta dan tutor 2 sedang memperhatikan penjelasan tutor 1

Gambar 3 adalah tutor kedua memberikan pengarahan terkait materi yang disampaikan oleh oleh tutor pertama via video conference google meet. 


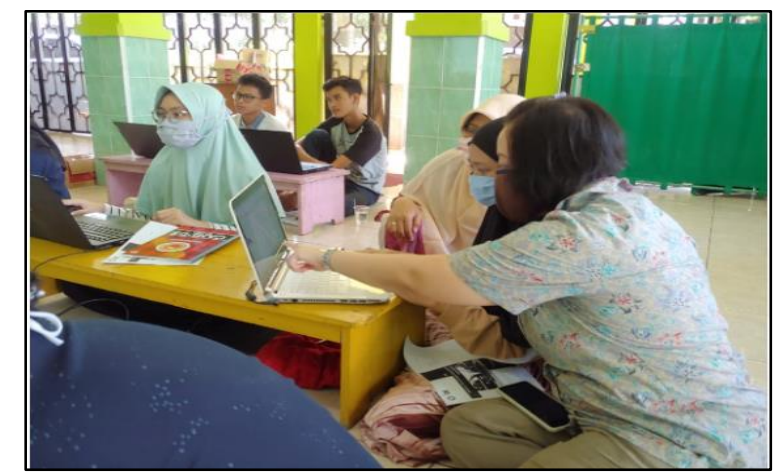

Gambar 3. Tutor 2 sedang membantu peserta

\section{Hasil Evaluasi Kegiatan Pengabdian Masyarakat}

Pada bagian ini akan diuraikan hasil evaluasi kegiatan PKM pelatihan digital academics writing denganmenggunakan Microsoft Word, butir- butir pertanyaan mengacu pada kuisioner pelatihan pembuatan presentasi Interaktif (Juanita et al., 2019), dan rinciannya adalah sebagai berikut:

a) Isi materi pelatihan jelas dan mudah dipahami

Dari hasil kuesioner yang disebarkan dapat diketahui bahwa $90 \%$ peserta sangat setuju dengan pernyataan bahwa "isi materi pelatihan jelas dan mudah dipahami" maka pada gambar 4 menunjukan $90 \%$ setuju dengan pernyataan ini menunjukan bahwa ini menunjukkan mayoritas responden setuju bahwa materi pelatihan jelas dan mudah di mengerti oleh peserta pelatihan.

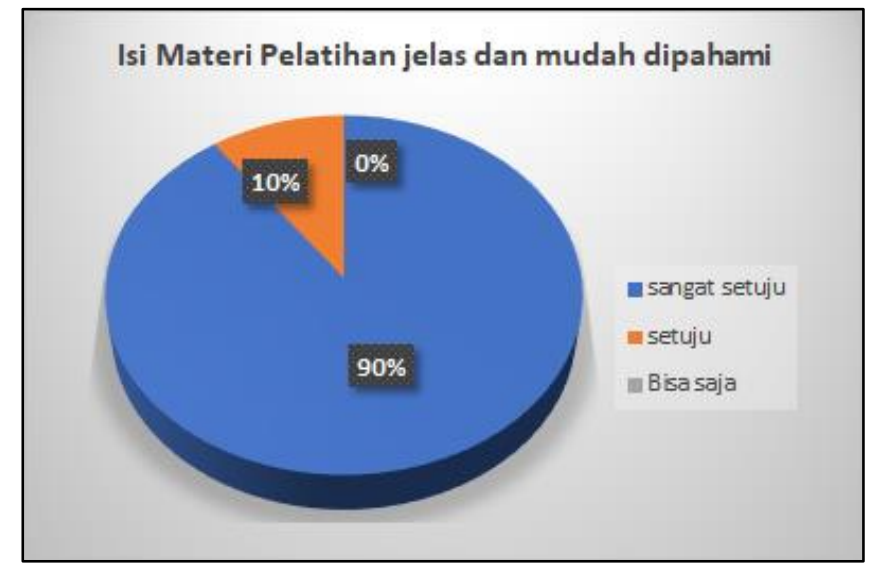

Gambar 4. Hasil kuisioner materi pelatihan jelas dam mudah dipahami

b) Tutor member kesempatan untuk bertanya

Dari hasil kuesioner yang disebarkan dapat diketahui bahwa $80 \%$ peserta sangat setuju dengan pernyataan bahwa "Tutor member kesempatan untuk bertanya" dengan pernyataan ini digambarkan pada gambar 5 , ini berarti mayoritas responden setuju bahwa tutor member kesempatan peserta untuk bertanya sehingga memudahkan peserta dalam memahami materi yang disampaikan. 


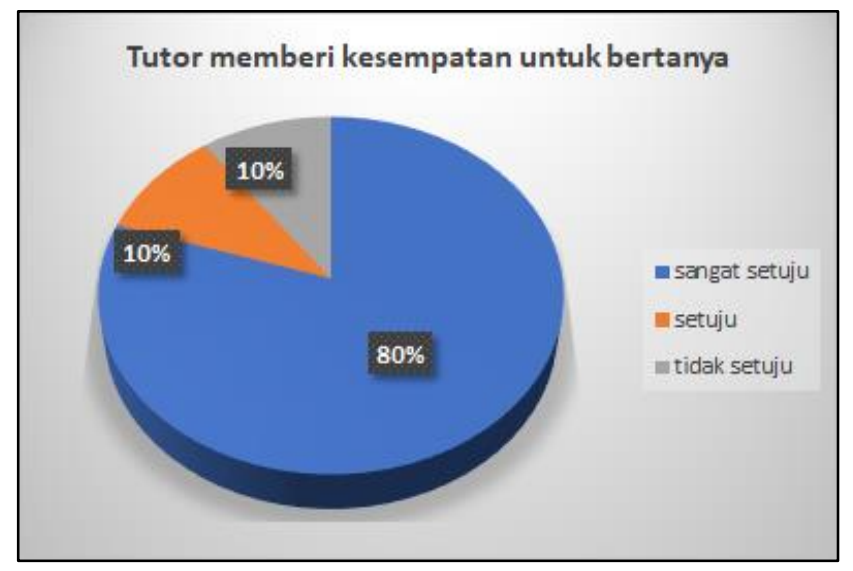

Gambar 5. Hasil kuisioner tutor member kesempatan untuk bertanya

c) Tutor menjawab pertanyaan dengan jelas dan mudah dipahami

Dari hasil kuesioner yang disebarkan dapat diketahui bahwa $90 \%$ peserta sangat setuju dengan pernyataan bahwa "Tutor menjawab pertanyaan dengan jelas dan mudah dipahami" dengan pernyataan ini digambarkan pada gambar 6 .

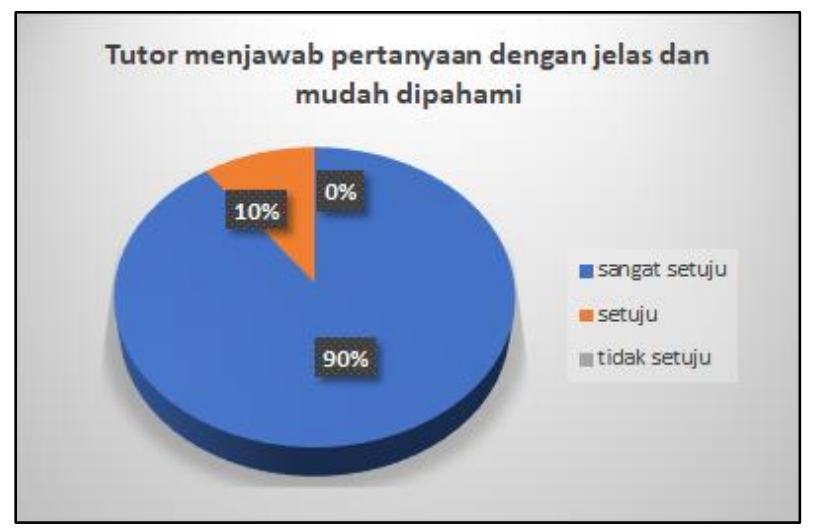

Gambar 6. Hasil kuisioner tutor menjawab pertanyaan denganjelas dan mudah dipahami

d) Para Tutor membantu peserta pelatihan untuk memahami materi dengan baik

Dari hasil kuesioner yang disebarkan dapat diketahui bahwa 70\% peserta sangat setuju dan 30\% menyatakan setuju dengan pernyataan bahwa "Para Tutor membantu peserta pelatihan untuk memahami materi dengan baik" denganpernyataan ini digambarkan pada gambar 7 .

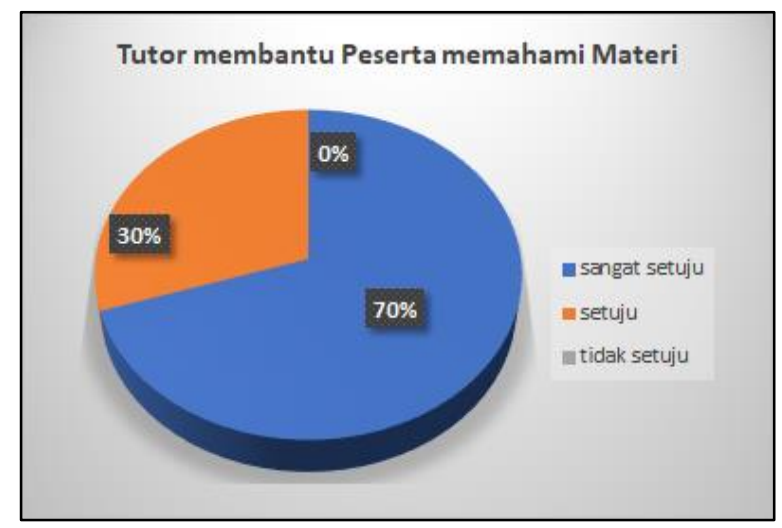

Gambar 7. Hasil kuisioner para tutor membantu untuk memahami materi yang disampaikan 
e) Tutor memberikan contoh latihan secara jelas dan mudah dipahami

Dari hasil kuesioner diketahui bahwa peserta yang setuju sebesar $40 \%$ dengan pernyataan bahwa "Tutor memberikan contoh latihan secara jelas dan mudah dipahami" maka pada gambar 8 menunjukan terdapat $60 \%$ peserta menyatakan sangat setuju dengan pernyataan ini.

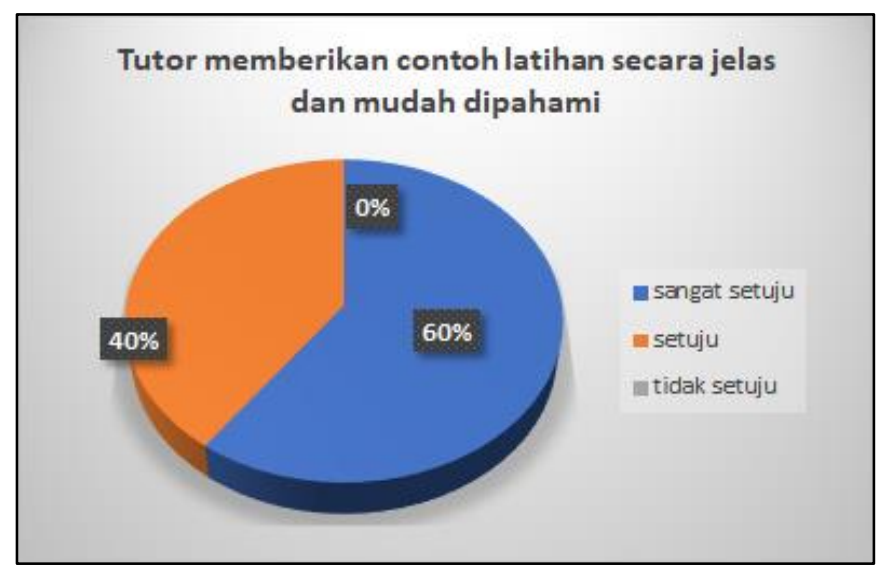

Gambar 8. Hasil kuisioner para tutor member contoh latihan secara jelas dan mudah dipahami

f) Fasilitas Komputer sesuai dengan kebutuhan Pelatihan

Hasil kuesioner yang disebarkan kepada peserta menunjukan bahwa $30 \%$ peserta yang setuju dengan pernyataan bahwa "Fasilitas komputer sesuai dengan kebutuhan pelatihan" maka pada gambar 9 menunjukan $40 \%$ peserta menyatakan sangat setuju dengan pernyataan ini.

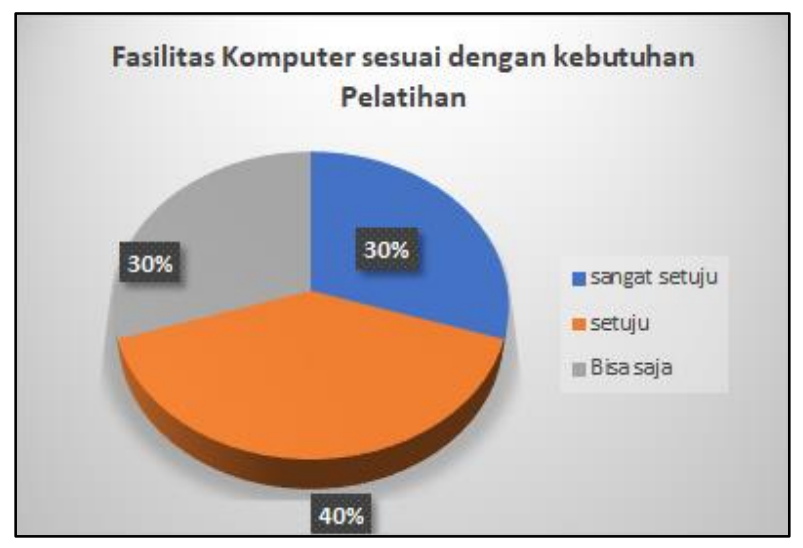

Gambar 9. Hasil kuisioner fasilitas komputer sesuai dengan kebutuhan pelatihan

g) Evaluasi bahwa pelatihan untuk meningkatkan keterampilan dalam Digital Academics Writing berbasis COST

Berdasarkan hasil evaluasi terdapat $71 \%$ peserta terindikasi dapat meningkatkan keterampilan nya dalam penulisan makalah yang memenuhi unsur comparative, objective, systematic dan trusted (COST) dan masih terdapat $29 \%$ peserta yang msih belum memahami dan belum memiliki peningkatan keterampilan dalam penulisan makalah berbasis COST, grafik digambarkan di gambar 10 


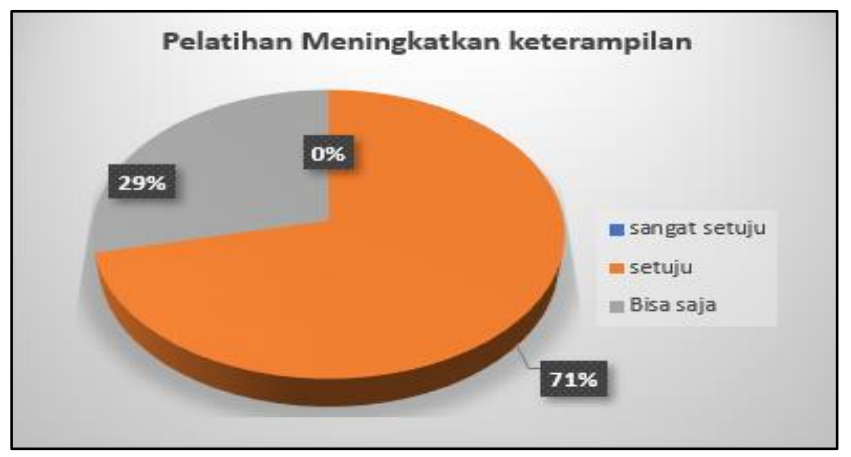

Gambar 10. Hasil kuisioner pelatihan meningkatkan keterampilan dalam penulisan berbasis COST

Berdasarkan dari hasil kuisioner diatas, rata -rata hasil kuisioner menurut kategori persentase (Supina, 2013) termasuk dalam kategori tinggi kaitannya dengan evaluasi hasil pembelajaran. Hal ini dibuktikan dengan hasil persentase yang menjawab sangat setuju yang mencapai $71 \%$

\section{Kesimpulan}

Berdasarkan dari hasil penelitian ini para peserta dapat menelaah kajian yang tepat dengan tema, peserta sudah mengetahui bagaimana mencari kajian yang tepat seperti mencari di Google Scholar (GS) dan Scopus secara berimbang sesuai dengan kebutuhan, peserta juga sudah dapat melakukan pencarian literatur dengan menggunakan aplikasi pengelola seperti Mendeley, peserta juga sudah bisa membuat paraphrasing secara sederhana, disamping itu juga peserta sudah mengetahui dan memahami struktur penulisan sesuai standard dan memiliki urutan yang runut disertai analisis yang logis dan objektif.

Pada dasarnya, para remaja memiliki kemauan untuk menulis karya ilmiah akan tetapi masih belum sesuai dengan standar ilmiah yang berlaku umum. Ini ditunjukkan dengan kemauannya untuk memperbaiki draft makalah yang sesuai dengan standar ilmiah yang baik. Karena sebagian besar peserta terbiasa menulis essay maka diperlukan untuk meyesuaikan dengan format penulisan makalah yang berbasis COST.

Perlu adanya kontinuitas dari kegiatan menulis karya ilmiah bagi para remaja khususnya pelajar dan mahasiswa, dengan bekerja sama dengan Sekolah sehingga dapat selalu terpantau dengan baik perkembangannya. Perlu dibentuk sebuah Wadah untuk menyalurkan kegiatan menulis yang diprakarsai oleh dinas pendidikan setempat.

\section{Ucapan Terima Kasih}

Ucapan Terima Kasih Kami sampaikan kepada Universitas Budi Luhur sebagai penyandang dana sehingga kegiatan pengabdian kepada masyarakat ini dapat terlaksana dengan baik

\section{Referensi}

Aminatun, L. E. R. (2017). Implementasi Teknik Penilaian Proyek dan Penilaian Sejawat Untuk Menilai Kompetensi Menulis Proposal Siswa Kelas XI SMA Negeri Karangpandan [Universitas Muhammadiyah Surakarta]. http://eprints.ums.ac.id/52279/ 
Hernawati, K. (2013). Optimalisasi Pemanfaatan Fitur Microsoft Word DalamPenyusunan Karya IImiah Bagi Guru. https://adoc.tips/artikel-kegiatanppm882ee1d50083864d77f09dcc175c2ba286149.html

Ikhwani, Y. (2015). Pelatihan Aplikasi Microsoft Word 2013 Pada Smp H. A. Johansyah. A Banjarmasin. Al-Ikhlas, 1(1), 11-14. https://www.researchgate.net/publication/337907054_Pelatihan_Aplikasi_microsoft_word_201 3_pada_SMP_HAJA

Juanita, S., Pramusinto, W., \& Anif, M. (2019). Peningkatan sumber daya manusia pada yayasan ummah mulia bangsa di tangerang dalam pemanfaatan internet sebagai media publikasi dan literasi infomasi. Prosiding SENDI_U 2019. Universitas Stikubank. 117-123.

Karmilasari, Kurniawan, A. B., \& Pertiwi, A. (2014). Pengembangan Model Alternatif Praktikum Jaringan Komputer Secara Mandiri Berbasis TIK. Jurnal Nasional Pendidikan Teknik Informatika (JANAPATI), 3(3), 118. https://doi.org/10.23887/janapati.v3i3.9821

Munawwaroh, Z. (2018). Menyusun makalah yang baik dan Benar. http://mp.fitk.uinjkt.ac.id/wpcontent/uploads/2018/09/MODUL-WOKELAH-MP-2018-created-Zahrotul-MmunawwarohM.Pd_.pdf

Nasih, A.M. (2013). Metode dan Teknik Pembelajaran Pendidikan Agama Islam. PT Refika Aditama.

Persadha, D. A. K. (2016). STUDI KOMPETENSI KEMAMPUAN MENULIS DI KALANGAN MAHASISWA. MUADDIB, 06(01), 1-20. https://doi.org/10.24269/muaddib.v6n1.2016.1-20

Press, U. S. A. (2018). Teknik Penulisan Karya IImiah (Sugeng Kurniawan (ed.)). UIN Sunan Ampel Press.

Sari, R., Fitriyani, A., \& Prabandari, R.D. (2020). Optimalisasi Penggunaan MS. Word dan MS. Excel Pada Siswa SMP PGRI Astra Insani Bekasi. Jurnal ABDIMAS (Pengabdian Kepada Masyarakat) $U B J, 3(2), 95-104$.

Supina. (2013). Pengaruh Motivasi Terhadap Hasil Belajar Siswa Kelas XC pada Mata Pelajaran Ekonomi di SMA. Artikel Penelitian Universitas Tanjungpura: Pontianak. https://jurnal.untan.ac.id/index.php/jpdpb/article/view/3330/3349

Wahab, A.A. (2012). Metode dan Model-Model Mengajar; Ilmu Pengetahuan Sosial (IPS). Alfabeta. 